\title{
The IHRA Working Definition of Antisemitism
}

The recent surge in antisemitic rhetoric, representations, and violence has led to growing recognition that democracies must pay closer attention and take specific steps to combat this problem. Existential questions have been raised about the viability of continued Jewish life in Europe-a community that has existed in Europe for millennia. Were this to change, so too would the future of Europe as a democratic and pluralistic society. In the words of Frans Timmermans, First Vice President of the European Commission in January of 2015-“If there's no future for Jews in Europe, there's no future for Europe."1

I will here focus on one of the most important international efforts to deal with the problem, the two Working Definitions of the International Holocaust Remembrance Alliance (IHRA), which was founded in 2000, at the Stockholm Forum and based on the Declaration issued there. Until January 2013, the organization was known as the Task Force for International Cooperation on Holocaust Education, Remembrance, and Research.

The IHRA is a thirty-one nation "intergovernmental body whose purpose is to place political and social leaders' support behind the need for Holocaust education, remembrance and research."2 It is composed of national delegations headed by senior government representatives and selected experts, and it is broken into Academic, Education, and Museums and Memorials Working Groups, as well as committees such as the Committee on Antisemitism and Holocaust Denial. As a member of the US delegation, I have participated in the IHRA since it began, and for the last six years, I chaired the Committee on Antisemitism and Holocaust Denial. In that capacity, I introduced the "Working Definition of Antisemitism," which was adopted by the IHRA in May 2016 in our plenary meeting in Bucharest. ${ }^{3}$

1 "Paris Attacks: Timmermans Warns of Jewish Exodus," BBC News, January 21, 2015, https:// www.bbc.com/news/world-europe-30924276.

2 "About us," The International Holocaust Remembrance Alliance, accessed July 28, 2018, https://www.holocaustremembrance.com/index.php/about-us.

3 Cf. "Working Definition of Antisemitism," International Holocaust Remembrance Alliance, issued May 26, 2016, https://www.holocaustremembrance.com/news-archive/working-definitionantisemitism.

Ә OpenAccess. () 2019 Mark Weitzman, published by De Gruyter. (cc) BY-NC-ND This work is licensed under the Creative Commons Attribution-NonCommercial-NoDerivatives 4.0 License. 
This process began with the adoption in October 2013 of a "Working Definition of Holocaust Denial and Distortion" of which I was the lead author. ${ }^{4}$ The key element in that definition was the inclusion of Holocaust distortion, for while it is easy to condemn Nazi sympathizers like David Irving, or the hardcore Holocaust denial of the Iranian government, it is harder to deal with the problem of those who do not flatly deny that there was a Shoah but distort it for their own ideological reasons. Thus, the rewriting of the historical narrative to whitewash local collaborators by governments presents a different challenge than some posting on social media. IHRA, by virtue of its being the only "intergovernmental body dedicated to the memory of the Holocaust," ${ }^{5}$ became the natural venue to take on this issue, and although it took five years to achieve consensus (which is required for formal adoption), we succeeded in finally getting it adopted. I am going to return to this issue a little later.

The Stockholm Declaration also contained the mandate to fight antisemitism as well, stating "With humanity still scarred by [...] antisemitism and xenophobia, the international community shares a solemn responsibility to fight those evils." ${ }^{6}$ Furthermore, when the Committee on Antisemitism and Holocaust Denial was established under the Norwegian Chair, it was set up in order to

form a common approach [emphasis added] to address the upsurge in antisemitism and Holocaust denial and trivialization. The Committee on Antisemitism and Holocaust Denial is tasked with assessing the situation and submitting to the Plenary an annual recommendations on measures to be taken to fight antisemitism in all its different forms. ${ }^{7}$

Thus, the directive to the Committee and to the IHRA was to take advantage of the IHRA's unique position as the only intergovernmental body that deals solely with issues related to the Holocaust and antisemitism and to gain the support of leaders of political and civil society for action on those issues. Further, the struc-

4 Cf. "Working Definition of Holocaust Denial and Distortion,” International Holocaust Remembrance Alliance, issued October 10, 2013, https://www.holocaustremembrance.com/workingdefinition-holocaust-denial-and-distortion

5 "The Holocaust in Public Discourse. Use and Abuse," International Holocaust Remembrance Alliance, issued November 6, 2015, https://www.holocaustremembrance.com/conferences/hol ocaust-public-discourse-use-and-abuse.

6 "Stockholm Declaration: A Commitment Shared by 32 Member Countries," International Holocaust Remembrance Alliance, accessed March 18, 2019, https://www.holocaustremembrance. com/index.php/stockholm-declaration.

7 “Antisemitism and Holocaust Denial," International Holocaust Remembrance Alliance, accessed March 18, 2019, https://2015.holocaustremembrance.com/focus/antisemitism-and-hol ocaust-denial. 
ture of the IHRA, which brings together political leaders and experts from the member countries (the "common approach" emphasized above), gives the IHRA an advantage in achieving practical political benefits based on expert opinion.

It was our feeling that in order to begin to address the problem of antisemitism, there must be clarity about what antisemitism actually is. This is not a simple question; in 1990, the American historian Gavin Langmuir published a major work entitled Towards a Definition of Antisemitism ${ }^{8}$ which highlighted the difficulty in narrowing the conceptual framework with which to view antisemitism historically. Langmuir distinguished between anti-Judaism, described as a rational response to a competing religion and antisemitism as an irrational response to an invented Jewish threat. Recently, the New York University historian David Engel, in his essay "Away from a Definition of Antisemitism," argued that the term itself was historically anachronistic and its uncritical application could create the false impression of an abstract, disembodied, and eternal "antisemitism." On the other hand, the leading expert on antisemitism in the post-World War II era, the late Robert Wistrich, described antisemitism as "the longest hatred," a description that has now become standard in many circles. ${ }^{10}$ Finally, David Nirenberg in his important book, Anti-Judaism: The Western Tradition, attempts to steer a middle path of not historicizing the past but at the same time being sensitive to its present impact. ${ }^{11}$ And that's citing just some of the historians; we haven't (and won't) begin to address the theologians, both Jewish and non-Jewish, the philosophers and political scientists, the psychologists and social scientists such as Adorno and Horkheimer of the Frankfurt School and others who have all offered their own definitions. So, as you can see, the question of which definition to choose was not simple. But, one thing was clear; given the sense of urgency that we were operating under, we could not afford to draft a new definition and debate it for another five years. So I proposed that we use the EUMC/FRA definition (with some editing), which Dina Porat has discussed previously, and in early 2014 the Committee unanimously agreed. ${ }^{12}$

The next step involved the political dimension of the actual adoption. I met with the future Romanian Chair, Ambassador Mihnea Constaninescu during the

8 G. Langmuir, Towards a Definition of Antisemitism (Berkeley: University of California Press, 1996).

9 Cf. D. Engel, "Away from a Definition of Antisemitism," in Rethinking European Jewish History, ed. J. Cohen and M. Rosman (Oxford: Littman Library of Jewish Civilization, 2009), 30-53. 10 Cf. R. S. Wistrich, Antisemitism: The Longest Hatred (New York: Schocken Books, 1991).

11 Cf. D. Nirenberg, Anti-Judaism: The Western Tradition (New York: Norton, 2013).

12 Cf. the contribution by Dina Porat in this volume, $\mathrm{xx}-\mathrm{xx}$. 
IHRA Manchester Plenary of December 2014, and he agreed to make the Definition one of his primary goals during the Romanian Chairmanship of 2016. That was a key step; not only did it ensure that the definition had the weight of the Chair behind it, which made saying no to it more difficult for the other countries since they in turn would want and expect support for their own projects when they assumed the Chair. But even more importantly, when the Romanians took it on they ensured that the Definition could not be viewed as a parochial Jewish or Israeli initiative, or just as negatively an American or Anglo-American initiative (since the US, UK, and Canada were already enthusiastic supporters). This was one of my goals from the very beginning of the process, and it reflected the attitude and composition of the Committee on Antisemitism and Holocaust Denial, which like the composition of the IHRA delegates themselves was probably predominantly not Jewish (probably because no one has ever surveyed the religion of the delegates). Instead, the Romanian championing of the Definition ensured that it was viewed as a European initiative, aimed at solving a European problem.

The next two and a half years involved some very intensive political work that culminated in the adoption of the Definition in the May 2016 Bucharest Plenary. The major sticking point for some of the countries that initially resisted coming on board involved the examples that related to Israel. One of our solutions was to move the paragraph that declared that the legitimate criticism of Israel could not be viewed as antisemitic up in the text to give it greater prominence (immediately following the emphasized section).

And, I have to say, as difficult as the process was, since it required consensus from thirty-one countries, and it was very tough at times, without the personal commitment of Ambassador Constantinescu we never would have achieved our goal. His efforts were truly vital. Still, we were jointly editing the document during the lunch break of the plenary meeting, and it was touch and go before Ambassador Constantinescu was able to declare consensus had been reached. Ambassador Constantinescu's personal commitment to this issue was immeasurable; despite some bruising political battles, he never wavered in working toward adoption of the text. We became good friends during this process, and he was always optimistic and encouraging while maintaining his gentle humor and poise throughout the most difficult times. His untimely death in 2017 was a tragic loss, but the rapid adoption of the Working Definition stands as a worthy memorial to his great achievement in fighting antisemitism.

So where do we stand today, three years later? Well, on one hand the acceptance of the Definition, as you have heard, has actually exceeded expectations, or at least my own. It has now been adopted or endorsed by a number of countries including the United Kingdom (12 December 2016), Israel (22 January 2017), Aus- 
tria (25 April 2017) Scotland (27 April 2017), Romania (25 May 2017), Germany (20 September 2017), Bulgaria (18 October 2017), Belgium (14 December 2018), Lithuania (24 January 2018), Republic of North Macedonia (6 March 2018), the Netherlands (27 November 2018), Slovakia (28 November 2018), Republic of Moldova (18 January 2019), Czech Republic (25 January 2019), Greek Ministry of Education (11 February 2019), Hungary (18 February 2019), and France (20 February 2019). ${ }^{13}$ The US State Department posted the Working Definition on its website saying "the United States now uses this working definition and has encouraged other governments and international organizations to use it as well," ${ }^{14}$ and the US Department of Education has also announced its use of the Working Definition. ${ }^{15}$ The official Canadian government website also has announced that it "strongly supports the working definition of antisemitism."16

According to Michael Whine of the CST, the definition has now been adopted by 160 local "elected government bodies," including the Cities of London and Manchester. ${ }^{17}$ In Germany, the Berlin State Police have adopted it as well, and in the US, Western Washington University recently became the first American University to officially adopt it for their campus. ${ }^{18}$ Significantly, in June 2017 the European Parliament adopted a resolution that "calls on the Member States and the Union institutions and agencies to adopt and apply the working definition of anti-Semitism employed by the International Holocaust Remembrance Alliance (IHRA) in order to support the judicial and law enforcement authorities in their efforts to identify and prosecute anti-Semitic attacks more efficiently and effectively, and encourages Member States to follow the example of the UK

13 For the latest list of adoption or endorsement by countries or international organizations, see https://www.holocaustremembrance.com/working-definitions-and-charters.

14 “Defining Anti-Semitism," U.S. Department of State, accessed March 18, 2019, https://www. state.gov/s/rga/resources/267538.htm.

15 Cf. "Department of Education Embraces State Department Definition of Anti-Semitism," Congressman Brad Sherman: Serving the San Fernando Valley, accessed March 18, 2019, https:// sherman.house.gov/media-center/press-releases/department-of-education-embraces-state-de partment-definition-of-anti.

16 "Freedom of Religion or Belief," Government of Canada, accessed March 18, 2019, https:// international.gc.ca/world-monde/issues_development-enjeux_developpement/human_rightsdroits_homme/freedom_religion-liberte_religion.aspx?lang=eng

17 M. Whine, Personal message to the author, February 28, 2019.

18 Cf. J. Hughes, "Defining Antisemitism and its Contemporary Importance with Mark Weitzman,” The AS Review, October 30, 2017, https://wp.wwu.edu/theasreview/2017/10/30/definingantisemitism-and-its-contemporary-importance-with-mark-weitzman/. 
and Austria in this regard." ${ }^{\text {"19 }}$ The same resolution also called on member states to "appoint national coordinators on combating antisemitism." ${ }^{20}$ Following that, in November 2018 the Council of the European Union

Calls on the member states that have not done so yet to endorse the non-legally binding working definition of antisemitism employed by the International Holocaust Remembrance Alliance (IHRA) as a useful guidance tool in education and training, including for law enforcement authorities in their efforts to identify and investigate antisemitic attacks more efficiently and effectively. ${ }^{21}$

And UN Secretary-General António Guterres has acknowledged "the efforts of the 31 member countries of the International Holocaust Remembrance Alliance to agree on a common definition of anti-Semitism."22

Finally (and perhaps most significantly) Wikipedia has deemed it "the most widely adopted definition of antisemitism around the world."23

However, before I conclude, I want to point out that there are some challenges as well. The BDS movement, along with antisemitic anti-Zionists (like Alison Weir) have focused on the Definition and attempted to discredit it by various means. ${ }^{24}$ Initially they claimed that it was meant to inhibit and criminalize

19 Cf. European Parliament, "Combating Anti-semitism: European Parliament Resolution of 1 June 2017 on Combating Anti-Semitism (2017/2692(RSP))," issued June 1, 2017, http://www.euro parl.europa.eu/doceo/document/TA-8-2017-0243_EN.pdf?redirect, 2.

20 Ibid., 3.

21 Council of the European Union, "Draft Council Declaration on the Fight against Antisemitism and the Development of a Common Security Approach to Better Protect Jewish Communities and Institutions in Europe,” issued November 30, 2018, http://data.consilium.europa.eu/doc/ document/ST-14966-2018-INIT/en/pdf, 7.

22 A. Guterres, " Remarks to High-Level Event on the Power of Education for Countering Racism and Discrimination: The Case of anti-Semitism,” issued September 26, 2018, https://www.un. org/sg/en/content/sg/speeches/2018-09-26/power-education-countering-racism-and-discrim ination-remarks.

23 “Antisemitism,” Wikipedia, accessed December 6, 2018, https://en.wikipedia.org/wiki/Antisemitism.

24 Cf. A. Weir, "International Campaign is Criminalizing Criticism of Israel as Antisemitic," If Americans Knew: What every American needs to know about Israel/Palestine, accessed December 6, 2018, https://ifamericaknew.org/history/antisemitism.html. Weir's antisemitism has been pointed out by many, including from those in the anti-Zionist camp. For one such a critique, see the "Statement on Complaint Filed Regarding Alison Weir and If Americans Knew," issued July 16, 2015, by the Steering Committee of the US Campaign to End the Israeli Occupation at http:// jewssansfrontieres.blogspot.com/2015/07/if-anti-racists-knew-alison-weir.html. A similar statement was issued by the anti-Zionist Jewish Voice for Peace group, cf. "Jewish Voice for Peace Statement on Our Relationship with Alison Weir," issued June 15, 2015, accessed December 6, 
anti-Israel protest and criticism; when that failed because of the Definitions robust defense of legitimate criticism mentioned earlier, they have recently tried a new attack, claiming that the text in the box (which does not mention Israel) was the only officially adopted definition and the rest was just illustrations that have no standing. This would, in effect, decouple the text from anything directly related to Israel and thus create a totally neutered definition unmoored from any current reality that includes Israel. Of course, that fails on two grounds-first, the text they would allow itself states

Antisemitism is a certain perception of Jews, which may be expressed as hatred toward Jews. Rhetorical and physical manifestations of antisemitism are directed toward Jewish or non-Jewish individuals and/or their property, toward Jewish community institutions and religious facilities. ${ }^{25}$

One could easily make the case that "Rhetorical and physical manifestations of antisemitism [...] directed to Jewish [...] individuals [...] community institutions and religious facilities" ${ }^{26}$ could also cover antisemitism related to Israel. Further, at the request of some British questioners, Ambassador Constantinescu and I issued a statement that states

We can confirm that the definition itself (as stated in the text of the adopted definition) is part of the entire document, including examples, that was officially adopted (as one piece) by the IHRA Plenary on 26 May 2016. There is no question about that and any assertion otherwise is absolutely false or misleading. ${ }^{27}$

A second challenge is the current situation in Poland. I could speak for a long time about this, as I have been involved with it for the past few years. Indeed, in December 2016, I was a part of a four member delegation representing the other 30 member nations of IHRA, together with Ambassador Michael Baier, former legal advisor to the Austrian Foreign Ministry and currently Head of Delegation of Austria's IHRA delegation, Dr. David Silberklang of Yad Vashem and Anthony Julius, the eminent English expert on antisemitism and Deborah Lipstadt's lawyer in the David Irving case. The delegation was sent to Warsaw on a diplomatic mission to discuss the issue with senior Polish officials at the Ministry of

2018, https://jewishvoiceforpeace.org/jewish-voice-for-peace-statement-on-our-relationshipwith-alison-weir/.

25 "Working Definition of Antisemitism."

26 Ibid.

27 The statement was published in M. Whine, “Applying the Working Definition of Antisemitism," Justice 61 (Fall 2018): 14. 
Foreign Affairs, Ministry of Justice and the Sejm, and in March 2017, I testified in Congress on this issue. ${ }^{28}$ Obviously we didn't make much headway with the Poles, and the situation has clearly deteriorated, but between what is happening in Poland now, which clearly falls under the definition of both antisemitism and Holocaust distortion as defined in the IHRA definitions. ${ }^{29}$ With the actions of Poland and other countries, such as Hungary, Croatia, Ukraine, and Russia which also have shown state activities that embrace Holocaust distortion, we are facing a new challenge to the historical narrative of the Holocaust. The implications are grave and not only for Jews; as many have noted, the impact of the Holocaust has been a major factor in shaping the liberal basis that underlies post World War II Europe and the animating of the political and social consensus that has until now rejected any mainstream legitimization of antisemitism. The recent attempts to distort the historical reality of the Shoah serve as the spearhead of the efforts to revive and reinvigorate old xenophobic and antisemitic extreme nationalist ideologies.

My discussion here does not extend to the United States because I am limiting my remarks to countries that have enacted, or are in the process of enacting state activities such as laws, memorials, curriculum, etc. in this area; I am not referring to statements by individual politicians no matter how reprehensible they are.

Brief mention must also be made of those who have expressed opposition to the definition on free speech grounds. To this I can only point out that in the text of the definition, immediately following the emphasized description in the box, comes the explicit statement that "criticism of Israel similar to that leveled against any other country cannot be regarded as antisemitic." ${ }^{30}$ And, the definition itself is clearly labeled "Legally non-binding," so I think our intent is clear to any fair-minded reader.

28 For the Poland mission, see "IHRA Delegation Visits Poland," International Holocaust Remembrance Alliance, issued December 14, 2016, accessed December 6, 2018, https://www.hol ocaustremembrance.com/media-room/stories/ihra-delegation-visits-poland. For my Congressional testimony, issued March 22, 2017, see https://docs.house.gov/meetings/FA/FA16/ 20170322/105755/HHRG-115-FA16-Wstate-WeitzmanM-20170322.pdf.

29 In January 2018, the right-wing Law and Justice government in Poland passed an amendment to the Act on the Institute of National Remembrance. The law prohibits any attribution of responsibility for Nazi atrocities, including the Holocaust, to either "the Polish state or the Polish nation.” For more information cf. e.g., D. Davison, “The unsettling denialism in Poland's 'National Remembrance' Law,” Open Democracy, issued July 26, 2018, accessed December 6, 2018, https://www.opendemocracy.net/en/can-europe-make-it/unsettling-denialism-in-polands-national-remembrance-law/.

30 "Working Definition of Antisemitism." 
To conclude, I would like to propose some related policy suggestions. One would obviously be to follow up on the European Parliament and the Council of Europe resolutions that countries adopt the definition and appoint a special coordinator. Second would be the implementation of the definition at all levels of society where applicable; in other words it could be used in education, in the media, in law enforcement and legal circumstances etc. Third would be adoption by other international organizations, such as the OSCE, UN, UNESCO etc.-although those are extremely long shots. Fourth, since the conference is built on the premise that we want to influence policy makers, I am proposing an immediate action-namely the issuing of a resolution in the name of the conference condemning the current wave of antisemitism in Poland and calling on the government to reverse course. It might not change anything, but it would at least be a moral statement that would demonstrate our commitment to the theme of this conference. $^{31}$

Mark Weitzman is a Director of Government Affairs for the Simon Wiesenthal Center. He is a member of the official US delegation to the International Holocaust Remembrance Alliance where he spearheaded the IHRA's adoption of the Working Definition of Antisemitism and the Working Definition of Holocaust Denial and Distortion. A winner of the 2007 National Jewish Book Award, he is currently co-editing the Routledge History of Antisemitism, scheduled for publication in 2020.

\section{Bibliography}

An End to Antisemitism! "Official Statement Opposing Poland's Amendment of the Act on the Institute of National Remembrance.” Issued February 20, 2018. https://anendtoantisemi tism.univie.ac.at/home-news/news/news/offical-statement-opposing-polands-amend ment-of-the-act-on-the-institute-of-national-remembrance.

Congressman Brad Sherman: Serving the San Fernando Valley. "Department of Education Embraces State Department Definition of Anti-Semitism.” Accessed March 18, 2019. https://sherman.house.gov/media-center/press-releases/department-of-education-em braces-state-department-definition-of-anti.

Council of the European Union. "Draft Council Declaration on the Fight against Antisemitism and the Development of a Common Security Approach to Better Protect Jewish

31 The statement was indeed issued at the end of the conference. Cf. "Official Statement Opposing Poland's Amendment of the Act on the Institute of National Remembrance," An End to Antisemitism!, issued February 20, 2018, https://anendtoantisemitism.univie.ac.at/home-news/ news/news/offical-statement-opposing-polands-amendment-of-the-act-on-the-institute-of-na tional-remembrance. 
Communities and Institutions in Europe." Issued November 30, 2018. http://data.con silium.europa.eu/doc/document/ST-14966-2018-INIT/en/pdf.

Davison, Dan. “The Unsettling Denialism in Poland's 'National Remembrance' Law." Open Democracy. Issued July 26, 2018. Accessed December 6, 2018. https://www.open democracy.net/en/can-europe-make-it/unsettling-denialism-in-poland-s-national-remem brance-law/.

Engel, David. "Away from a Definition of Antisemitism." In Rethinking European Jewish History, edited by Jeremy Cohen and Moshe Rosman, 30-53. Oxford: Littman Library of Jewish Civilization, 2009.

European Parliament. "Combating Anti-semitism: European Parliament Resolution of 1 June 2017 on Combating Anti-Semitism (2017/2692(RSP))." Issued June 1, 2017. http://www.eu roparl.europa.eu/doceo/document/TA-8-2017-0243_EN.pdf?redirect.

Government of Canada. "Freedom of Religion or Belief.” Accessed March 18, 2019. https://in ternational.gc.ca/world-monde/issues_development-enjeux_developpement/human_ rights-droits_homme /freedom_religion-liberte_religion.aspx?lang=eng.

Guterres, António. "Remarks to High-Level Event on the Power of Education for Countering Racism and Discrimination: The Case of anti-Semitism." Issued September 26, 2018. https://www.un.org/sg/en/content/sg/speeches/2018-09-26/power-education-counter ing-racism-and-discrimination-remarks.

Hughes, Josh. "Defining Antisemitism and its Contemporary Importance with Mark Weitzman.” The AS Review, October 30, 2017. https://wp.wwu.edu/theasreview/2017/10/ 30/defining-antisemitism-and-its-contemporary-importance-with-mark-weitzman/.

International Holocaust Remembrance Alliance. “About us.” Accessed July 28, 2018. https:// www.holocaustremembrance.com/index.php/about-us.

—. "Antisemitism and Holocaust Denial." Accessed March 18, 2019. https://2015.holocaus tremembrance.com/focus/antisemitism-and-holocaust-denial.

—_. "Stockholm Declaration: A Commitment Shared by 32 Member Countries." Accessed March 18, 2019. https://www.holocaustremembrance.com/index.php/stockholm-declara tion.

—. "The Holocaust in Public Discourse. Use and Abuse." Issued November 6, 2015. https:// www.holocaustremembrance.com/conferences/holocaust-public-discourse-use-andabuse.

—. "IHRA Delegation Visits Poland." Issued December 14, 2016. https://www.holocaus tremembrance.com/media-room/stories/ihra-delegation-visits-poland.

—_. "Working Definition of Antisemitism." Issued May 26, 2016. https://www.holocaus tremembrance.com/news-archive/working-definition-antisemitism.

—. "Working Definition of Holocaust Denial and Distortion." Issued October 10, 2013. https://www.holocaustremembrance.com/working-definition-holocaust-denial-and-dis tortion.

—_. "Working Definitions and Charters: Policy Guidance from IHRA experts." Accessed March 18, 2019. https://www.holocaustremembrance.com/working-definitions-and-charters.

Jewish Voice for Peace. "Jewish Voice for Peace Statement on Our Relationship with Alison

Weir." Issued June 15, 2015, accessed December 6, 2018. https://jewishvoiceforpeace. org/jewish-voice-for-peace-statement-on-our-relationship-with-alison-weir/.

Langmuir, Gavin. Towards a Definition of Antisemitism. Berkeley: University of California Press, 1996. 
N.N. "Paris Attacks: Timmermans Warns of Jewish Exodus.” BBC News, January 21, 2015. https://www.bbc.com/news/world-europe-30924276.

Nirenberg, David. Anti-Judaism: The Western Tradition. New York: Norton, 2013.

Steering Committee of the US Campaign to End the Israeli Occupation. "Statement on Complaint Filed Regarding Alison Weir and If Americans Knew." Issued July 16, 2015, accessed December 6, 2018. http://jewssansfrontieres.blogspot.com/2015/07/if-anti-rac ists-knew-alison-weir.html.

U.S. Department of State. “Defining Anti-Semitism.” Accessed March 18, 2019. https://www. state.gov/s/rga/resources/267538.htm.

Weir, Alison. "International Campaign is Criminalizing Criticism of Israel as Antisemitic." If Americans Knew: What every American needs to know about Israel/Palestine. Accessed December 6, 2018, https://ifamericaknew.org/history/antisemitism.html.

Weitzman, Mark. "Testimony: Hearing on 'Anti-Semitism Across Borders'." Issued March 22, 2017. https://docs.house.gov/meetings/FA/FA16/20170322/105755/HHRG-115-FA16Wstate-WeitzmanM-20170322.pdf.

Wikipedia. "Antisemitism.” Accessed December 6, 2018. https://en.wikipedia.org/wiki/Anti semitism.

Wistrich, Robert S. Antisemitism: The Longest Hatred. New York: Schocken Books, 1991.

Whine, Michael. "Applying the Working Definition of Antisemitism." Justice 61 (Fall 2018): $9-16$. 
